\title{
Diseminasi informasi zero waste oleh Yayasan Pengembangan Biosains dan Bioteknologi
}

\author{
Umy Fatkhah', Yunus Winoto ${ }^{2}$, Ute Lies Siti Khadijah ${ }^{3}$ \\ 1,2,3Program Studi Perpustakaan \& Sains Informasi, Universitas Padjadjaran \\ J1. Raya Bandung-Sumedang Km. 21, Jatinangor, Sumedang, Jawa Barat, 45363

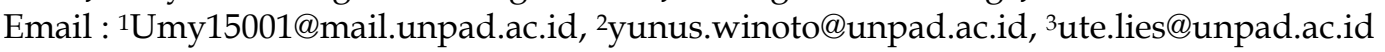

Received: March 2020; Accepted: May 2020; Published: June 2020

\begin{abstract}
The Bioscience and Biotechnology Development Foundation (YPBB) managing organic and non organic waste through a program called zero-waste. This study aimed to determine the zero waste information dissemination activities at YPBB. The study used a qualitative method with a case study approach. Data collection techniques used were observations, interviews, and document analysis. The analysis was performed by data reduction, data presentation, and concluding. Study results indicated that zero-waste information dissemination activities were through Programs Zero-Waste Lifestyle (ZWL) and Zero-Waste Cities (ZWC). The ZWL Program comprised training involving partners. Communicators in the ZWL Program were YPBB voluntary trainers, that the message conveyed was informative, using a clear and to understands word approach and a humorous approach. The media used presentation slides as instructional media, organic nonorganic waste, takakura, and biopore drills as instructional aids. The ZWL Program participants were middle and upper-middle urban communities. The kelurahan or RW implemented the Zero Waste Cities Program (ZWC). Communicators in this program were RW heads and cadres, that give messages were persuasive and educational, conveyed through posters and WhatsApp groups. The study concludes that the dissemination of zero waste information through the Zero-Waste Lifestyle (ZWL) and Zero Waste Cities (ZWC) Programs are viewed from communication elements, namely communicators, messages, media and communication elements that are already running and by the program planned. The conclusion this research shows that the dissemination of zero waste information through ZWL and ZWC according to the communication element is already in progress, and according to the planned program.
\end{abstract}

Keywords: Information dissemination; Zero waste; Foundation for Bioscience and Biotechnology Development

\begin{abstract}
Abstrak
Yayasan Pengembangan Biosains dan Bioteknologi (YPBB) mengelola sampah organik dan non organik melalui sebuah program bernama bebas sampah (zero waste). Penelitian ini bertujuan untuk mengetahui kegiatan diseminasi informasi zero waste di YPBB. Metode penelitian yang digunakan adalah kualitatif dengan pendekatan studi kasus. Adapun teknik pengumpulan data melalui observasi, wawancara, dan analisis dokumen. Hasil penelitian menunjukkan bahwa kegiatan diseminasi informasi zero waste dilakukan melalui Program Zero Waste Lifestyle (ZWL) dan Program Zero Waste Cities (ZWC). Program ZWL berupa pelatihan yang melibatkan mitra. Komunikator Program ZWL yaitu trainer dari relawan YPBB, yang menyampaikan pesan bersifat informatif, menggunakan pendekatan kata yang jelas dan mudah dipahami, dan pendekatan bersifat humor. Media lembar (slide) persentasi digunakan sebagai instructional media. Adapun sampah organik dan non organik, takakura, bor biopori sebagai instructional aids. Komunikan dalam Program ZWL ialah masyarakat menengah dan menengah ke atas di kota. Program Zero Waste Cities (ZWC) merupakan program yang diterapkan di tingkat Kelurahan atau RW. Komunikator dalam program ini adalah Ketua RW dan Kader, yang menyampaikan pesan bersifat persuasive edukatif, dengan menggunakan poster dan grup WhatsApp. Simpulan penelitian ini menunjukkan bahwa diseminasi informasi zero waste melalui Program ZWL dan ZWC sesuai unsur komunikasi sudah berjalan, dan telah sesuai program yang telah direncanakan.
\end{abstract}

Kata Kunci: Diseminasi informasi; Nol sampah; Yayasan Pengembangan Biosains dan Bioteknologi 


\section{PENDAHULUAN}

Pada hari Sabtu, 27 April 2019, Yayasan Pengembangan Biosains dan Bioteknologi (YPBB) mengadakan Workshop Zero Waste Lifestyle (ZWL) di Cihapit, Bandung. Selama kegiatan ini, para peserta workshop belajar mengenai kegiatan Zero Waste Lifestyle, mulai dari pengenalan jenis sampah, penyakit yang diakibatkan sampah, banyaknya sampah yang dihasilkan Kota Bandung, jumlah sampah yang diangkut ke Tempat Pemrosesan Akhir (TPA), dan cara pengolahan sampah. Selain itu, para peserta pun diminta menyebutkan nama dan jenis sampah yang diambil secara acak dari kotak yang disediakan. Berdasarkan kegiatan ini, para peserta dapat mengingat jenis dan pemilahan sampah karena lebih interaktif.

Kegiatan workshop Zero Waste Lifestyle memberikan edukasi kepada para peserta mengenai pengolahan sampah organik agar tidak tercampur dengan sampah non organik, dan tertumpuk di TPA. Salah satunya melalui praktik membuat takakura, yaitu keranjang pengolahan sampah organik menjadi kompos. YPBB sendiri sering melakukan kegiatan serupa di Kota Bandung. Dengan demikian, hal ini membuat peneliti tertarik meneliti mengenai kegiatan diseminasi informasi Zero Waste Lifestyle oleh YPBB pada masyarakat luas terutama masyarakat Kota Bandung.

Zero waste atau bebas sampah selalu dikaitkan dengan lingkungan. Hal ini sejalan dengan konsep pembangunan berkelanjutan, bahwa aspek lingkungan harus selalu menjadi perhatian karena lingkungan sekitar merupakan tempat manusia serta organisme lain hidup. Oleh karena itu, salah satu tujuan Zero Waste Lifestyle adalah pengurangan penggunaan sampah, terutama sampah plastik karena berdampak terhadap kerusakan lingkungan. Hal ini dibenarkan Arisyanti (2018) yang mengatakan bahwa dampak dari sampah plastik dapat bertahan hingga bertahun-tahun sehingga mengakibatkan pencemaran lingkungan.

Wahyudi, Prayitno, and Astuti (2018) menuturkan bahwa persentase kontribusi sampah plastik di Indonesia dilihat dari persentase negara-negara Asia Tenggara yang nilainya tidak jauh berbeda. Namun secara riil, produksi sampah Indonesia sangat besar yakni sekitar 189 kilo per hari karena jumlah penduduk negara lebih banyak dibandingkan negara Asia Tenggara lainnya. Maka, produksi sampah pun lebih banyak. Oleh karena itu, perlu adanya upaya dalam mengatasi masalah sampah.

Sampah (waste) pun diartikan, "Sebagai sesuatu yang tidak digunakan, tidak terpakai, tidak disenangi atau disukai yang dibuang berasal dari kegiatan manusia dan tidak terjadi dengan sendirinya" (Bahri, 2015). Hal ini yang menjadikan sampah sampai saat ini di Indonesia masih menjadi masalah yang belum terselesaikan (Purwaningrum, 2016). Ada beberapa faktor penanganan sampah di Indonesia belum dapat diatasi dengan baik. Salah satunya pertambahan jumlah penduduk yang akan berpengaruh terhadap produksi jumlah sampah yang dihasilkan. Selain itu, masyarakat pun belum memiliki kesadaran dalam mengelola sampah. Hal ini sesuai pendapat Septiani, Arianie, Risman, Handayani, and Kawuryan (2019) yang mengatakan bahwa minimnya pengetahuan dan penyuluhan mengenai dampak sampah berpengaruh terhadap kurangnya kesadaran masyarakat dalam mengelola sampah. 
Ada beberapa penelitian terdahulu dalam menunjang penelitian ini. Pertama, penelitian Siswantini (2017) mengenai aktivitas komunikasi lingkungan melalui gerakan literasi pengelolaan sampah di kawasan bebas sampah di Kota Bandung. Penelitian ini menggunakan metode kualitatif dengan jenis penelitian studi kasus. Berdasarkan hasil penelitian, terungkap bahwa kolaborasi antara pemerintah dan masyarakat dalam menginformasikan wacana bebas sampah menjadi pendorong munculnya inovasi sosial dan teknologi. Selain itu, masyarakat bersemangat dalam menyebarkan gaya hidup bebas sampah sehingga menjadi pendorong gerakan massal dalam mewujudkan kota bebas sampah.

Kedua, penelitian Djaffar (2017) menggunakan metode penelitian kualitatif mengenai diseminasi teknologi informasi pada masyarakat nelayan di Kabupaten Takalar dan Baru. Hasil penelitian menunjukkan bahwa diseminasi teknologi informasi masyarakat nelayan di Kabupaten Takalar dan Barru kurang terlaksana dengan baik. Hal ini karena tingkat pengetahuan dan motivasi masyarakat dalam pengetahuan teknologi masih kurang.

Penelitian Siswantini (2017) dan Djaffar (2017), memiliki persamaan dan perbedaan dengan penelitian ini. Penelitian pertama memiliki persamaan dalam mengkaji masalah pengelolaan sampah, sedangkan penelitian kedua membahas tentang diseminasi informasi. Adapun perbedaan kedua penelitian dengan penelitian ini ialah kegiatan diseminasi informasi dalam Program Zero Waste Lifestyle.

YPBB sendiri adalah salah satu lembaga nonprofit profesional yang memiliki beberapa program diseminasi informasi yaitu Zero Waste Lifestyle (ZWL) dan Program Zero Waste Cities (ZWC). Berkaitan dengan program diseminasi informasi zero waste ini, salah seorang narasumber, menyatakan.

“Tujuannya supaya menjadi titik masuk orang untuk mulai melakukan sesuatu dengan sampah mereka di rumahnya. Dia bisa melakukan dua hal tadi, satu memilah, yang kedua memanfaatkan. Terutama isi (sampah) organiknya diurus sendiri di rumah menjadi kompos. Jadi, orang bisa melihat bahwa mengolah sampah itu mudah, hanya dua langkah" (Anilawati, wawancara, September 4, 2019).

Berdasarkan kutipan wawancara tersebut, diseminasi informasi mengenai zero waste atau bebas sampah yang dilakukan YPBB merupakan salah satu upaya untuk mengajak masyarakat agar peduli terhadap lingkungan. Selain itu, masyarakat pun diajak untuk aktif mengolah sampah yang berasal dari rumahnya masing-masing. YPBB berusaha memperkenalkan penerapan pola hidup zero waste pada masyarakat melalui pemilahan sampah organik dan non organik. Sampah organik kemudian diolah menjadi kompos. YPBB berperan membantu masyarakat dalam mencapai kualitas hidup yang tinggi dan berkelanjutan, untuk kehidupan sekarang dan generasi mendatang melalui gaya hidup yang selaras dengan alam (organik).

YPBB pun mengharapkan masyarakat memiliki kesadaran dalam menjaga bumi dan mengurangi produksi sampah di kegiatan sehari-hari. Hal ini mengingat Setyowati and Mulasari (2013) yang memaparkan bahwa penyebab kerusakan lingkungan adalah limbah plastik yang 
berbahaya dan masih sulit dikelola sehingga bumi memerlukan puluhan hingga ratusan tahun untuk mengurai limbah plastik.

YPBB aktif menyebarkan informasi mengenai kegiatan zero waste kepada masyarakat umum terutama di Bandung. Informasi mengenai kegiatan zero waste memang sangat penting dilakukan di Kota Bandung, sebagai bentuk cara dalam untuk mewujudkan Bandung Zero Waste City. Ini sesuai data yang dilansir Komari, Abdulhak, and Heryanto (2013) bahwa, "Produksi sampah di Kota Bandung didominasi oleh sampah rumah tangga, seperti limbah dapur dan sampah rumah tangga lainnya sebagai dampak dari berlangsungnya kehidupan sehari-hari setiap keluarga."

Informasi zero waste termasuk ke dalam informasi mengenai lingkungan. "Prinsip nol sampah atau zero waste merupakan konsep pengelolaan sampah yang didasarkan pada kegiatan daur ulang (recycle)" (Widiarti, 2012). Gerakan zero waste mengurangi produksi sampah dan menciptakan produk yang akan menghidupi masyarakat secara ekonomi local. Hal ini berpegang pada prinsip 5R yaitu refuse (menolak), reduce (mengurangi), reuse (menggunakan kembali), recycle (mendaur ulang), dan rot (membusukkan). Kelima prinsip ini bertujuan mengurangi produksi sampah dan memanfaatkan sumber daya alam secara bijak.

YPBB bertujuan menyebarkan informasi zero waste dan menerapkan pola hidup organik sesuai pembangunan berkelanjutan atau disebut Sustainable Development Goals (SDGs). Hal ini menyatakan bahwa pembangunan yang dilakukan harus bisa memperhatikan citacita tentang generasi mendatang agar dapat memanfaatkan lingkungan, seperti masyarakat saat ini. Demikian pula YPBB membantu masyarakat dalam mencapai kualitas hidup umat manusia yang tinggi, untuk generasi sekarang dan terlebih untuk generasi mendatang, melalui gaya hidup selaras dengan alam. Salah satunya penerapan pola hidup zero waste dan melakukan pengolahan sampah.

Selain itu, YPBB mengajak masyarakat untuk mulai mengolah sampah sendiri karena pengelolaan sampah saat ini dinilai masih kurang tepat. Sampah yang dikelola dengan tidak tepat dapat berdampak buruk. Berkaitan dengan hal ini, Mahyudin (2017) menuturkan bahwa sampah yang dikelola tidak baik dapat menurunkan estetika di sekitar tempat pembuangan sampah sehingga menimbulkan konflik antar masyarakat.

YPBB melakukan kegiatan diseminasi informasi zero waste agar masyarakat memiliki pengetahuan dan keterampilan mengenai isu lingkungan, terutama permasalahan sampah. Masyarakat yang melek informasi mengenai lingkungan akan mengetahui kerusakan yang ditimbulkan dan menyadari tindakan yang seharusnya dilakukan.

Konsep zero waste sendiri yakni kegiatan merancang, mengelola, dan memproses sampah tanpa pembakaran atau penguburan. Hal ini bertujuan mengubah gaya hidup masyarakat dalam menangani sampah dengan cara meniru siklus alam yang berkelanjutan. Adapun implementasi program ini adalah menghindari pembuangan sampah ke tanah, air atau udara yang membahayakan manusia, hewan, tumbuhan, serta lingkungan.

Tindak lanjut Program Zero Waste oleh YPBB adalah melakukan diseminasi informasi. Sesuai konteks komunikasi, 
kegiatan diseminasi hakikatnya adalah sebuah kegiatan komunikasi informasi. YPBB dalam konteks ini sebagai komunikator yang menyampaikan pesan berupa informasi tentang zero waste pada masyarakat yang bertujuan memengaruhi masyarakat agar menerapkan pola hidup zero waste, melalui pemilahan sampah di sekitar lingkungan atau di rumah.

Nurdiansyah (2013) mengatakan bahwa diseminasi informasi, "Dalam ilmu perpustakaan erta kaitannya dengan istilah publisitas dan promosi, oleh karenanya diseminasi seringkali dipersepsikan sebagai bagian dari promosi." Pendapat lain menuturkan bahwa,

"Diseminasi adalah merupakan sinonim dari kata penyebaran. Jadi pengertian diseminasi informasi adalah penyebaran informasi yang ditunjukkan kepada kelompok atau individu agar memperoleh informasi, timbul kesadaran, menerima, dan akhirnya memanfaatkan informasi tersebut" (Kusumajanti, Purnama, \& Priliantini, 2018).

Pengertian lain tentang diseminasi informasi pun dikemukakan Nurazizah (2018) yang mengatakan bahwa diseminasi informasi adalah kegiatan yang direncanakan kemudian disebarluaskan bagi masyarakat yang membutuhkan informasi. Tujuan diseminasi informasi sendiri adalah,

"Memberitahu atau paling tidak dengan informasi tersebut komunikan dapat berubah sikap karena karena mendapat penjelasan, pengalaman serta pola hidup budaya baru dalam komunitasnya" (Retnowati, 2014).

Sesuai rujukan di atas, diseminasi informasi hakikatnya adalah kegiatan komunikasi. Hal ini juga terlihat dari pengertian diseminasi menurut Ordoñez and Serrat (2017) bahwa diseminasi adalah proses interaksi dalam mengomunikasikan pengetahuan untuk target khalayak sehingga bisa digunakan yang mengarah pada perubahan. Diseminasi dipengaruhi lima yang hal saling berhubungan, di antaranya source (komunikator), content (pesan), context (konteks), medium (media), dan user (penerima).

Diseminasi informasi pun terkait komunikasi dalam penggunaan unsur $5 \mathrm{~W}+1 \mathrm{H}$ (Rodiah, Budiono, \& Rohman, 2018). Namun, proses komunikasi dan diseminasi informasi yang produktif hanya akan terjadi apabila sumber informasi mampu membuat penerima informasi percaya dan melakukan sesuatu sesuai dengan informasi yang diterimanya (Prihandoyo, 2014).

Unsur pertama dalam kegiatan diseminasi informasi zero waste adalah komunikator. Menurut Cangara (2018) komunikator merupakan kunci dari suatu kegiatan komunikasi. Sebuah proses komunikasi akan mengalami kegagalan atau tidak berhasil jika terjadi kesalahan pada unsur komunikator, misalnya komunikator kurang mampu dalam menyusun pesan, memilih media, atau memahami siapa yang menjadi audience. Oleh karena itu, untuk menjadi seorang komunikator yang baik Cangara (2018) menyebutkan ada beberapa hal yang harus diperhatikan, seperti penguasaan pesan yang akan disampaikan, kemampuan mengemukakan argumen secara logis, kemampuan intonasi bahasa, aspek bahasa tubuh yang dapat menarik perhatian audience, dan memiliki sense of humor untuk mengurangi rasa bosan bagi pendengar.

Unsur kedua dalam diseminasi informasi adalah menyangkut pesan (message). Pesan, segala sesuatu yang disampaikan seseorang dalam bentuk simbol yang terdapat persepsi dan diterima khalayak dalam serangkaian 
makna. Berkaitan dengan penyusunan pesan, Cangara (2018) mengatakan ada dua teknik dalam menyusun pesan one side issue dan two side issue. One side issue, yakni suatu teknik penyusunan pesan dengan cara menonjolkan isi kebaikan atau keburukan sesuatu. Sesuai konteks diseminasi informasi tentang Program Zero Waste, komunikator menyampaikan sisi baik dari program ini. Two side issue, yakni suatu teknik penyampaian pesan seorang komunikator dalam menyampaikan pesan, melalui penyampaian pesan dari sisi baik dan sisi buruk. Komunikator memberikan kesempatan pada khalayak untuk mengetahui dari pelbagai sudut pandang serta dipersilahkan menentukan informasi mana yang dianggap menguntungkan bagi mereka.

Cangara (2018) dalam aspek pesan kegiatan diseminasi informasi zero waste, menjelaskan tentang cara penyusunan pesan dilihat dari tujuan penyampaian pesan, bersifat informatif dan persuasif. Pesan yang bersifat informatif, artinya komunikator dalam menyampaikan pesan bertujuan memberikan informasi pada komunikan atau khalayak sasaran. Pesan yang bersifat persuasif, yaitu teknik penyusunan pesan yang bertujuan mengubah pengetahuan, sikap dan perilaku khalayak sesuai tujuan dari program yang dilakukan. Adapun konteks penyusunan pesan yang bersifat persuasif memiliki beberapa metode yang biasa dilakukan, seperti menggunakan fear appeal, emotion appeal, reward appeal serta metode motivational appeal.

Unsur ketiga dalam proses komunikasi yaitu media (medium). Secara sederhana media dapat diartikan sebagai segala sesuatu yang dapat digunakan untuk menyalurkan pesan, merangsang pikiran, perasaan, dan perhatian khalayak. Ketika kita memilih media komunikasi, maka kita harus mempertimbangkan karakteristik isi dan tujuan isi pesan yang ingin disampaikan.

Unsur keempat dalam proses komunikasi adalah komunikan atau khalayak sasaran. Sesuai konteks komunikan atau khalayak sasaran, dalam menciptakan suatu proses komunikasi yang efektif, maka seorang komunikator harus memahami siapa yang menjadi komunikan. Komunikan harus memiliki pemahaman mengenai kerangka pengetahuan (frame of reference) dan kerangka pengalaman (field of experience).

Ordoñez and Serrat menyatakan bahwa diseminasi informasi merupakan proses komunikasi yang terdiri dari unsur komunikan, pesan (informasi), media serta komunikan. Adapun kelima unsur diseminasi informasi tersebut dapat dijalankan melalui jawaban atas beberapa pertanyaan. Pertama, apa yang ingin disebarkan? Diseminasi hanya akan diterima dan sukses apabila dari awal terdapat kesamaan visi, dan pemahaman pesan yang disampaikan agar audience menerima dan mendapatkan manfaat.

Kedua, siapa target khalayak dan apa yang ditawarkan? Target atau penerima informasi penting untuk dilakukan identifikasi dan ditentukan sejak awal dalam merancang suatu cara dalam menumbuhkan kesadaran, pemahaman, dan model tindakan. Walaupun jumlah target khalayak banyak atau berasal dari semua kalangan, maka akan lebih baik jika sejak awal komunikator konsentrasi pada target yang membutuhkan informasi dan kemudian fokus pada kalangan tersebut.

Ketiga, kapan diseminasi dilakukan? Diseminasi tidak dapat dilakukan secara 
mendadak, maka harus ada persiapan dan latihan terlebih dahulu. Kegiatan latihan masuk dalam rencana diseminasi melalui identifikasi dan pengaturan lebih awal, dan realistis. Keempat, apa cara yang paling efektif dalam melakukan diseminasi? Laporan adalah output konkret yang dapat menjadi bukti bahwa telah dilaksanakan diseminasi. Namun, penting untuk mengevaluasi sarana yang efektif dan tepat dalam menemukan kebutuhan target khalayak. Berdasarkan sarana yang digunakan, maka akan dapat meningkatkan peluang sukses dalam diseminasi.

Kelima, siapa yang membantu diseminasi? Target khalayak pasti memiliki suatu acara, komunitas, atau kegiatan yang biasa diikuti, melalui kolaborasi. Kolaborasi dilakukan dengan pihak yang memiliki hubungan dengan khalayak sehingga diseminasi memiliki peluang sukses lebih besar. Selain itu, kolaborasi pun dapat mengurangi biaya. Keenam, bagaimana mempersiapkan strategi? Strategi diseminasi harus mencakup tujuan diseminasi, pengetahuan apa yang akan disebarkan, target khalayak, manfaat bagi penerima, metode diseminasi dan aktivitas yang menunjang, skala waktu (time scale) dan pertanggungjawaban, target, biaya dan evaluasi serta kriteria kesuksesan.

Ketujuh, bagaimana mengubah strategi ke dalam rencana diseminasi? Ketika menciptakan strategi diseminasi yang koheren belum tentu menghasilkan implementasi yang efektif. Suatu rangkaian tindakan yang jelas, harus ada artikulasi melalui cakupan tujuan, target khalayak, metode, sarana, ketepatan waktu, dan pertanggungjawaban. Kedelapan, bagaimana membiayai aktivitas diseminasi? Setelah mengubah strategi menjadi rencana diseminasi, kita perlu memastikan bahwa setiap aktivitas diseminasi telah diperhitungkan biayanya secara cermat. Sesuai rencana anggaran, semua aspek dari diseminasi harus diperhitungkan, misalnya dalam pengadaan pelatihan akan membutuhkan tempat, konsumsi peserta, transportasi, dan lain-lain. Hal ini harus masuk ke dalam anggaran, dan disiapkan jauh hari. Sembilan, bagaimana mengetahui kesuksesan dari diseminasi? Sebuah strategi diseminasi yang efektif akan terus menjadi efektif apabila hal ini dipandang sebagai evolusi dan secara teratur mengembangkan proses. Konteks pelaku dan penerima diseminasi akan berubah. Oleh karena itu, kiranya penting menempatkan mekanisme dalam meninjau kemajuan diseminasi melalui penentuan target sejak awal. Salah satu cara yang paling efektif untuk menentukan target dengan cara menghubungkan tujuan diseminasi sesuai kesadaran, dukungan dan kesukaan, pemahaman, keterlibatan, serta komitmen. Selain itu, terdapat contoh lain dalam melakukan identifikasi mengenai kelompok target, di antaranya target, skala waktu, alasan seleksi, dan kriteria kesuksesan.

Berdasarkan pertanyaan penelitian di atas, maka penelitian ini bertujuan mengetahui beberapa hal. Peneliti ingin mengetahui informasi kegiatan YPBB yang disebarkan kepada khalayak, target sasaran dari informasi yang disebarkan, waktu penyebaran informasi, waktu yang efektif dalam penyebaran informasi, pihak yang membantu YPBB dalam penyebaran informasi, strategi penyebaran informasi, rencana diseminasi, biaya aktivitas, dan kesuksesan diseminasi informasi. Sesuai tujuan penelitian ini, terlihat konsep 
Program Zero Waste yang dilakukan YPBB dalam mengelola sampah organik dan non organik. YPBB berusaha mengenalkan pengelolaan sampah yang ramah lingkungan pada masyarakat. Dengan demikian, peneliti tertarik mengkaji fenomena kegiatan diseminasi informasi pada Program Zero Waste oleh YPBB.

\section{METODE PENELITIAN}

Penelitian ini menggunakan pendekatan kualitatif melalui jenis penelitian studi kasus. Menurut Creswell (2016), metode penelitian kualitatif merupakan suatu pendekatan atau penelusuran dalam melakukan eksplorasi dan memahami suatu gejala. Peneliti dalam hal ini melakukan wawancara melalui pertanyaan yang agak luas kepada tiap informan untuk mengetahui gejala sentral tersebut. Informasi yang didapatkan dikumpulkan, dilakukan analisis dan interpretasi. Kualitas, nilai atau makna hanya diungkapkan melalui kata-kata, bahasa dan linguistik. Oleh sebab itu, bentuk data yang digunakan dalam penelitian ini bukan berbentuk angka, bilangan, skor atau nilai, peringkat atau frekuensi, yang biasanya dilakukan analisis menggunakan perhitungan matematis atau statistik.

Metode penelitian studi kasus dinyatakan sebagai, "Pendekatan studi kasus dapat memberi nilai tambah pada pengetahuan kita secara unik tentang fenomena individu, organisasi, sosial atau politik (Yin, 2019). Studi kasus memungkinkan untuk mempertahankan karakteristik holistik dan bermakna dari peristiwa kehidupan nyata, seperti siklus kehidupan seseorang, proses organisasional, manajerial, perubahan lingkungan sosial, hubungan internasional, dan kematangan industri.
Adapun yang menjadi kasus dalam penelitian ini adalah mengenai Program Zero Waste Lifestyle (ZWL) yang diadakan YPBB bersama Dompet Dhuafa Volunteer, sebagai mitra, dan Program Zero Waste Cities (ZWC) yang dilaksanakan di Kelurahan Neglasari Kecamatan Cibeunying Kaler, Kota Bandung.

Subjek penelitian ini adalah staf divisi kampanye zero waste di YPBB, serta masyarakat yang mendapatkan informasi melalui pelatihan ZWL maupun Program ZWC. Objek penelitian sendiri ialah kegiatan diseminasi informasi zero waste yang dilakukan YPBB. Sumber data penelitian meliputi data primer, yakni orang-orang yang terlibat dalam kegiatan diseminasi informasi zero waste yang dilakukan YPBB, mulai dari staf, tim lapangan hingga masyarakat yang menerima informasi. Peneliti memilih masyarakat sebagai sumber data primer karena sasaran utama Program ZWC adalah masyarakat di wilayah atau kawasan perumahan. Maka, peneliti memerlukan masukan dari masyarakat untuk mengetahui efektifitas komunikator dalam menyampaikan pesan, dan media yang digunakan YPBB dalam Program ZWC. Data sekunder penelitian berupa data tambahan berisi informasi yang akan melengkapi data primer, berupa dokumen baik yang tercetak seperti buku, jurnal, artikel, dan dokumen non cetak seperti rekaman/audio yang berhubungan dengan diseminasi informasi dan konsep zero waste. Teknik pengumpulan data dilakukan melalui observasi, wawancara, dan studi kepustakaan. Adapun teknik analisis data dilakukan melalui tahapan reduksi data, di antaranya proses seleksi, penentuan fokus, dan membuat ringkasan data dari catatan lapangan. Selain itu, 
tahap penyajian data berupa naratif, dan verikasi data dengan cara membandingkan data dari data awal observasi untuk mendukung pengumpulan data berikutnya.

\section{HASIL DAN PEMBAHASAN}

Berdasarkan paparan di awal tulisan, penelitian ini membahas mengenai kegiatan diseminasi informasi Program Zero Waste yang dilakukan YPBB. Lembaga ini adalah organisasi nonprofit dan non pemerintah, yang telah 25 tahun berdedikasi membantu masyarakat mencapai kualitas hidup umat manusia yang tinggi bagi generasi sekarang, dan generasi mendatang melalui gaya hidup selaras dengan alam. YPBB mempromosikan inovasi terbaik dalam pola hidup organik, dan membantu masyarakat untuk mengadopsi pola hidup tersebut secara efektif melalui program edukasi, dukungan kelompok, pengorganisasian masyarakat, serta dukungan teknologi dan infrastruktur. Saat ini, YPBB telah dikenal dengan kepemimpinannya dalam isu hidup organik melalui kampanye utama tentang zero waste.

YPBB berkembang berdasarkan kesadaran dalam mewujudkan visi dan misi yang strategis untuk kehidupan umat manusia di masa mendatang. YPBB pun memiliki idealisme yang kuat, organisasi yang solid, efisien, dan dirancang secara tepat. YPBB dikembangkan sebagai organisasi masyarakat dengan sistem pendukung yang profesional, transparan, dan efisien. Tim eksekutif YPBB secara intensif telah mengembangkan sistem kerja berskala organisasi yang tepat dalam meningkatkan jumlah pendukung dan terlibat dalam kerja YPBB secara signifikan.
YPBB, sejak tahun 2019, semakin meningkatkan kinerja melalui kerja sama beberapa staf yang berkualitas, dari berbagai disiplin ilmu yang mampu bekerja secara profesional, misalnya dengan pihak pemerintah, seluruh lapisan masyarakat, organisasi skala regional dan internasional. Hal ini bertujuan menggencarkan kampanye gaya hidup organik sesuai visi lembaga. YPBB pun terus meningkatkan kapasitas lembaga dalam pengelolaan platform kegiatan riset, pengembangan, dan pengelolaan pelayanan sesuai bidang keilmuan di bidang biosains dan bioteknologi.

YPBB sendiri mendapatkan dana utama berupa hibah berskala kecil (small grant) dari lembaga penyokong dana, donasi individu yang secara sukarela memberi dana, dan berdasarkan keahlian di bidang yang spesifik. Sampai saat ini, YPBB secara konsisten masih terus mengembangkan program pendanaan berbasis masyarakat. Salah satu aktivitas YPBB bernama Program Zero Waste (nol sampah), yang memiliki divisi khusus bernama divisi strategis. Divisi ini mengampanyekan gaya hidup organik melalui isu sampah sejak tahun 2005 hingga saat ini. Adapun tujuannya adalah mengampanyekan pemahaman dasar persoalan sampah dan memperkenalkan sistem pengelolaan sampah yang berwawasan lingkungan dan berkelanjutan. Target sasaran kampanye Program Zero Waste adalah orang dewasa dan kalangan masyarakat menengah ke atas di kota berupa pelatihan Zero Waste Lifestyle (ZWL) dan Zero Waste Cities (ZWC).

Diseminasi informasi dapat diartikan sebagai suatu kegiatan yang ditujukan kepada kelompok target atau individu agar mereka memperoleh informasi, 
timbul kesadaran, menerima, dan akhirnya memanfaatkan informasi tersebut. Informasi didapatkan setelah diadakan perencanaan yang matang, berpandangan jauh ke depan melalui diskusi atau forum lainnya yang sengaja diprogramkan agar mendapatkan kesepakatan dalam menciptakan inovasi.

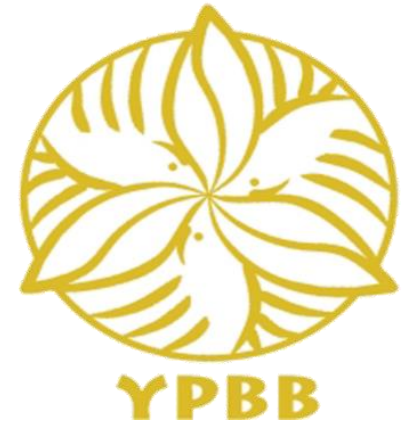

Gambar 1. Logo Yayasan Pengembangan

Biosains dan Bioteknologi (YPBB)

Sumber: YPBB, 2019

Sesuai konteks komunikasi, diseminasi informasi adalah kegiatan komunikasi itu sendiri. Hal senada juga dikemukakan Ordoñez and Serrat (2017), yang menyatakan bahwa diseminasi adalah proses interaksi dalam mengomunikasikan pengetahuan bagi target khalayak untuk digunakan pada hal yang mengarah untuk perubahan.

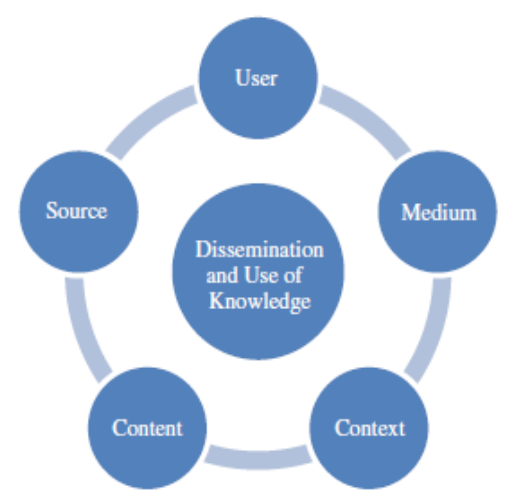

Gambar 2. Disemination and use of knowledge Sumber: Ordoñez and Serrat, 2017

Diseminasi dipengaruhi lima hal yang saling berhubungan, di antaranya source (komunikator), content (pesan), context (konteks), medium (media), dan user (penerima). Berdasarkan hasil penelitian ini, diseminasi informasi pada Program Zero Waste Lifestyle dan Program Zero Waste Cities dapat dikemukakan sebagai berikut.

Zero Waste Lifestyle (ZWL) adalah salah satu program YPBB dalam menyebarkan informasi zero waste. ZWL menjadi program pertama YPBB dalam menyebarkan informasi zero waste dan fokus pada isu sampah berupa pelatihan sejak tahun 2005. Pelatihan Zero Waste Lifestyle (ZWL) diadakan YPBB dengan kerja sama beberapa mitra, dari kelompok maupun individu. Adapun pengajuan permintaan kerja sama dapat dilakukan melalui media sosial YPBB seperti Facebook, Instagram, dan Twitter. Pihak mitra dapat menghubungi humas YPBB melalui media sosial tersebut dalam mengajukan kerja sama. Kemudian tim humas akan meneruskan informasi kerja sama kepada divisi kampanye zero waste, terutama pada tim yang menangani program ZWL dengan memperhatikan waktu, biaya operasional, dan teknis pelaksanaan yang akan dibahas dalam pertemuan tim kampanye dengan mitra.

Pertemuan ini dilakukan melalui dua cara, mitra mendatangi langsung kantor YPBB, atau mitra berkoordinasi dengan YBB dengan komunikasi jarak jauh melalui telepon, dan face to face interaction di aplikasi Skype. Hal ini dilakukan untuk menghemat waktu, tenaga, dan materi agar sesuai dengan visi YPBB, yakni mengajak manusia menerapkan pola hidup organik. Kini, mitra yang mendatangi kantor YPBB berkoordinasi mengenai kesepakatan kegiatan dianggap sudah tidak efisien lagi sehingga lebih baik menggunakan teknologi yang ada.

YPBB dan mitra yang bersepakat dalam kegiatan pelatihan akan 
menentukan hari kegiatan, waktu, tempat, dan biaya operasional yang harus dibayarkan mitra kepada YPBB. Adapun kesepakatan lain, seperti alat apa saja yang perlu disediakan oleh mitra agar kegiatan pelatihan berjalan efektif, seperti proyektor dan papan tulis. Jadi, YPBB dalam pelatihan ini bertugas memberikan pelatihan atau menyediakan materi, sedangkan mitra menyediakan tempat, waktu, mempersiapkan peserta, konsumsi, dan hal penunjang lain sesuai keperluan.

YPBB melalui Program ZWL, menyampaikan informasi dan melakukan pelatihan yang melibatkan pelatih (trainer), yakni orang yang dimasukkan YPBB untuk memberikan pelatihan ZWL. Berdasarkan hasil wawancara dengan salah seorang staf divisi kampanye zero waste dan supervisor pelatih ZWL menyatakan bahwa.

“Untuk pelatihan, kita ajak masyarakat buat jadi relawan, jadi trainer. Selain karena staf YPBB yang terbatas juga biar makin banyak orang di lingkar 2 YPBB. Lingkar 2 YPBB tuh orang yang pernah terlibat dalam berbagai kegiatan YPBB." (Anilawati, wawancara, September 4, 2019).

Pelatih (trainer) tidak terikat sebagai staf, namun bersifat relawan (volunteer). Relawan dalam konteks ini yaitu orang yang secara sukarela melakukan tugas sebagai pelatih YPBB tanpa tercatat sebagai staf YPBB. Sejak awal masuk, seorang pelatih memang dapat mengajukan klaim gaji dengan syarat bahwa gaji yang diterima dari pekerjaan utama tidak lebih dari gaji staf YPBB. Selain itu, perekrutan pelatih pun menjadi cara YPBB dalam melakukan diseminasi informasi zero waste. Ketika masyarakat tertarik menjadi pelatih, maka mereka akan mendapatkan pemahaman lebih dalam mengenai zero waste dan peluang menerapkan zero waste dalam kehidupannya akan lebih besar.

Perekrutan relawan dilakukan karena staf YPBB tidak banyak. Hal ini dilakukan untuk membangun relasi dan menambah basis komunitas orang-orang di lingkar 2 YPBB, yakni sebutan bagi orang yang pernah terlibat di kegiatan YPBB, contohnya pelatih (trainer), atau relawan dalam penelitian yang dilakukan YPBB. Namun demikian, ada beberapa tahapan yang harus dilalui sebelum menjadi pelatih (trainer) atau relawan.

Pertama, YPBB membuka pendaftaran trainer Zero Waste Lifestyle pada awal tahun dengan penandatanganan kontrak untuk satu tahun sebagai pelatih (trainer). Adapun untuk menjadi bagian dari tim relawan pelatih (trainer), YPBB memiliki beberapa persyaratan, a) memiliki kepedulian terhadap lingkungan, khususnya isu sampah, b) senang berbagi pengalaman dan pengetahuan pada orang lain, c) memiliki kemampuan dasar public speaking (tidak mudah demam panggung), d) bersedia mengikuti kegatan Training of Trainer (ToT) pada tanggal yang telah ditentukan, e) memiliki waktu luang yang ingin digunakan, dan f) berdomisili di Bandung, minimal untuk 1,5 tahun ke depan.

Kedua, YPBB mengadakan Training of Trainer (ToT) dalam satu hari. Pada tahap ini, calon pelatih (trainer) akan diberikan edukasi mengenai alur persampahan sebagai gambaran penyebab terbentuknya sampah, mulai dari Sumber Daya Alam (SDA), pengolahan sampah menjadi produk, produk sampah dijual dan didistribusikan, dibeli, dipakai di rumah tangga, hingga menjadi sampah kembali, dan berakhir di TPA. Saat pelatihan zero waste kepada masyarakat, pelatih (trainer) hanya memberikan materi tahap 
pembuangan sampah dari rumah hingga ke TPA saja. Walaupun begitu, calon pelatih (trainer) diberikan materi tersebut agar mereka memahami bagaimana sampah terbentuk dan melihat dari sudut pandang yang lebih luas. Ketiga, yakni penyelenggaraan program magang, di mana calon pelatih (trainer) akan diberikan waktu selama 2-3 bulan untuk mengisi minimal satu kegiatan pelatihan zero waste.

YPBB mengemas pesan Program ZWL dalam satu dokumen lalu dilakukan diseminasi informasi untuk menjadi acuan bagi seluruh staf dan pelatih (trainer) dalam menyampaikan informasi. Adapun penyusunan pesan tersebut dilakukan sejak pertama kali didirikan divisi kampanye zero waste, ditambah aktualisasi di bagian yang diperlukan tanpa mengubah subtansi.

Sesuai lembar (slide) presentasi yang disampaikan, terdiri dari beberapa bagian materi yang berupa fakta mengenai kondisi sampah saat ini, dan bagaimana cara mengatasi hal ini sesuai visi YPBB. Pertama, materi perjalanan sampah. Pelatih (trainer) meminta peserta untuk menuliskan perjalanan sampah dalam penyampaian pesan materi ini. Pelatih (trainer) memberi contoh sampah yang dikumpulkan dari rumah lalu dibuang ke mana, dan mengakhirinya menggunakan tanda tanya apabila peserta tidak mengetahui kelanjutannya. Di sini, peneliti melihat bahwa peserta sangat antusias. Saat pelatih (trainer) meminta peserta untuk menjelaskan hasil tulisannya, terdapat lima peserta yang mengangkat tangan. Kelima peserta tadi lalu memaparkan bagaimana alur sampah mereka di rumah, dan pelatih (trainer) menuliskannya di papan tulis.

Kedua, materi kondisi sistem persampahan. Hal ini terdiri dari banyaknya sampah yang dihasilkan Kota Bandung, bagaimana sistem yang diterapkan Kota Bandung dalam mengelola sampah, dijelaskan keefektifan pola penanganan sampah saat ini melalui sentralisasi sampah dikumpulkan di Tempat Penampungan Sementara (TPS) lalu diangkut ke Tempat Pemrosesan Akhir (TPA) secara masif yang menghabiskan dana besar. Pada bagian materi ini, peserta diberikan foto tumpukan sampah yang ada dipelbagai wilayah, TPS ilegal, dan kondisi TPA Leuwigajah yang sudah ditutup dan sempat longsor.

Selain itu, pelatih (trainer) pun mengajak peserta untuk mengungkapkan pikiran saat melihat foto TPA yang luasnya hektaran namun telah kelebihan sampah dan tidak muat lagi untuk menampung sampah. Ada empat peserta yang mengemukakan pendapat mengenai hal ini. Ketiga, materi dampak buruk sampah. Pelatih (trainer) dalam materi ini menyampaikan mengenai dampak buruk yang ditimbulkan sampah berkaitan dengan kesehatan. Di sini terlihat bahwa sebagian peserta menunjukkan keterkejutan, yang terungkap dari pernyataan satu peserta.

"Hah? saat trainer memaparkan informasi bahwa sampah yang dibakar menyebabkan penyakit autism dengan mengatakan "baru tau yah? Iya, mungkin karena pembakaran sampah sudah biasa dilakukan. Kita menganggap itu hal yang lumrah. Padahal sebenarnya sangat berbahaya dan banyak sekali penyakit yang ditimbulkan" (A. Rahayu, wawancara, September 4, 2019). 
Adapun mengenai penanganan masalah sampah, Diandara (2017) mengatakan bahwa saat ini paradigma pengelolaan sampah yang bertumpu pada pendekatan akhir sudah diganti dengan paradigma yang memandang sampah sebagai sumber daya yang mempunyai nilai ekonomi dan dapat dimanfaatkan, seperti untuk energi, pupuk kompos, dan lain-lain. Pengelolaan sampah sesuai paradigma ini dilakukan dengan cara pengurangan sampah, pembatasan, penggunaan kembali, serta daur ulang. Adapun kegiatan penanganan sampah meliputi pemilahan, pengumpulan, pengangkutan, pengolahan, dan pemrosesan akhir.

Keempat, materi mengenai undangundang mengenai sampah. Pelatih (trainer) dalam penyampaian materi ini menjelaskan bahwa Indonesia sudah ada regulasi yang mengatur mengenai persampahan, yaitu larangan untuk mengubur, membakar, dan membuang sampah sembarangan, seperti termuat dalam UU Nomor 18 Tahun 2008. Pesan ini disampaikan untuk menunjukkan bahwa persoalan sampah sebenarnya sudah diatur pemerintah.

Adapun kegiatan pelatihan Program ZWL menggunakan beberapa media, di antaranya lembar (slide) persentasi, contoh sampah organik dan non organik, keranjang takakura, dan bor biopori. Pelatih (trainer) menggunakan slide untuk menyampaikan informasi pelatihan ZWL melalui tampilan gambaran dan video. Peserta dapat melihat dan menonton video melalui media ini. Ada beberapa peserta juga yang terlihat memotret materi yang ditampilkan dalam slide tersebut.

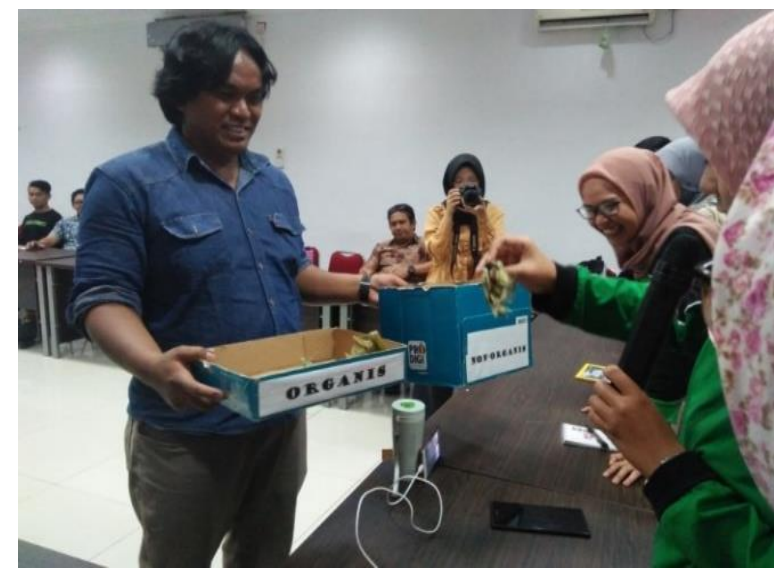

Gambar 3. Cara memilah sampah

Sumber: Kegiatan Workshop ZWL, 2019

Pelatih (trainer) menggunakan contoh sampah organik dan non organik untuk menyampaikan materi mengenai jenis sampah. Pada gambar 3, peserta diminta praktik memilah sampah organik dan non organik. Sampah tersebut telah disediakan tim kampanye sehingga peserta tinggal mengambil secara acak, menyebutkan nama sampah dan jenis sampah, kemudian memasukan sampah ke dalam kotak jenis sampah yang telah disediakan. Semua peserta terlihat antusias dan dapat memilah sampah dengan benar.

Keranjang takakura, adalah keranjang yang berfungsi untuk mengompos sampah organik lembut yang dihasilkan di rumah. Pelatih (trainer) dalam pelatihan ZWL mempraktikkan cara mengompos menggunakan takakura dan cara membuatnya dalam versi singkat. Peserta terlihat antusias mengetahui bentuk takakura dari jarak dekat. Peserta pun diperbolehkan melihat lapisan yang membentuk takakura. Pelatih (trainer) kemudian mencontohkan memotong sisa sayuran lalu memasukkannya ke dalam takakura. 


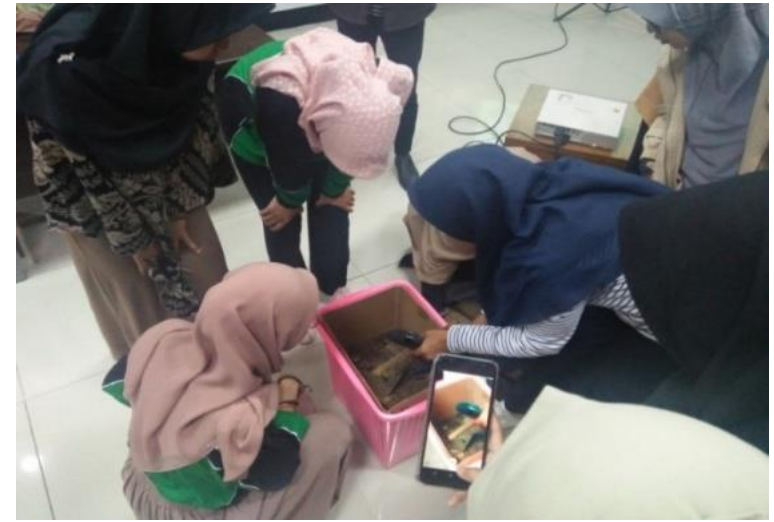

Gambar 4. Praktik mengompos dengan takakura Sumber: Kegiatan Workshop ZWL, 2019

Adapun bor biopori adalah lubang dalam tanah yang digunakan untuk resapan air dan mengompos sampah organik. Praktik ini dilakukan dengan cara memutar bor. Mengingat kegiatan pelatihan dilakukan dalam ruangan, maka praktik dilakukan dengan tidak benarbenar membuat lubang namun hanya memberi contoh cara menggunakan alatnya saja. Penyampaian materi ini dilakukan dua pelatih (trainer), pertama menjelaskan materi, dan kedua mencontohkan cara menggunakan bor biopori. Di mana bor biopori yang digunakan adalah milik YPBB sendiri.

Komunikan dalam Program ZWL yang diadakan YPBB bersama mitra Dompet Dhuafa Volunteer (DDV) terdiri dari 28 orang, dengan rentang usia 19-30 tahun. Saat itu, peserta berkenalan satu per satu. Pelatih (trainer) meminta peserta memperkenalkan nama, asal (bisa asal instansi atau asal daerah), dan tujuan mengikuti pelatihan. Pada umumnya tujuan peserta mengikuti pelatihan ini untuk belajar cara pengelolaan sampah secara baik dan benar.

ZWC merupakan program yang dijalankan YPBB sebagai amanat UndangUndang Nomor 18 Tahun 2008 tentang Pengelolaan Sampah, bahwa sampah harus dikelola sesuai metode dan teknik yang berwawasan lingkungan.

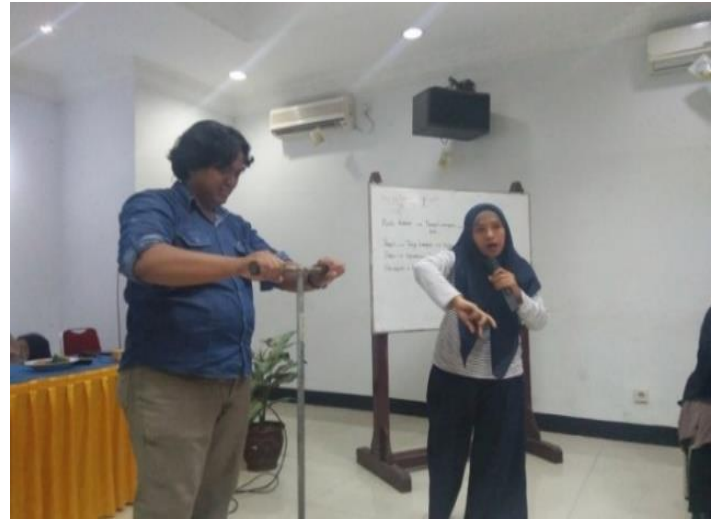

Gambar 5. Praktik membuat biopori Sumber: Kegiatan Workshop ZWL, 2019

Selain itu, Program ZWC dilatarbelakangi Peraturan Pemerintah Nomor 81 Tahun 2012 tentang Pengelolaan Sampah Rumah Tangga dan Sampah Sejenis Sampah Rumah Tangga. Sesuai kedua peraturan ini, semua lembaga atau komunitas berperan besar dalam mengelola sampah. Kita semua pun diharapkan dapat menerapkan prinsip pengurangan sampah dari lingkungan keluarga, sampah rumah tangga.

Program ZWC dilaksanakan sejak tahun 2019, dan telah berjalan di Kecamatan Cibeunying Kaler, Kecamatan Coblong, Kelurahan Babakan Sari, dan Kelurahan Sempolsari di Kota Bandung. Dua desa di Kabupaten Bandung, dan 40 Rukun Warga (RW) di Kota Cimahi. Studi kasus dalam penelitian ini yaitu program ZWC yang dilaksanakan di RW 07 Kelurahan Neglasari, Kota Bandung. Adapun yang menjadi target program ZWC adalah pengurangan polusi sampah ke sungai dan ke laut melalui perbaikan sistem pengumpulan dan daur ulang sampah.

Proses komunikasi terjadi pada masyarakat pada Program Zero Waste Cities (ZWC) melalui Door To Door Education (DTDE) dan Door To Door Collection (DTDC) dan kegiatan diseminasi informasi yang meliputi beberapa tahapan. Pada Program Zero Waste Cities, 
terdapat beberapa pihak yang bertugas sebagai komunikator, yaitu ketua RW, petugas kebersihan, dan Kader. Tiap komunikator dipilih berdasarkan alasan yang berbeda. Program ZWC melibatkan banyak pihak dalam pelaksanaan program karena merupakan program ini ditujukan bagi warga di suatu daerah. Tepatnya pada lingkungan RW untuk menerapkan sistem pengolahan sampah yang baru. Maka, YPBB memerlukan waktu dan Sumber Daya Manusia (SDM) dalam pelaksanaan Program ZWC yang berasal dari warga local sendiri.

Ketua RW sebagai komunikator dalam program ini karena Ketua RW memiliki kewenangan dan kebijakan mengenai sistem pengelolaan sampah di lingkungannya. Hal ini dibenarkan salah satu narasumber yang merupakan Manajer Program ZWC Kota Bandung.

"Jadi awalnya program ini diterapkan di tingkat Kelurahan, dan berharap semua RW dan seluruh jajarannya dapat mengikuti. Ternyata, sulit. Karena RW punya sistem dan kewenangan sendiri. Petugas (kebersihan) pun banyaknya diatur oleh RW. Jadi, akhirnya kita langsung ke RW" (Fauzi, wawancara, September 4, 2019).

Ketua RW sebagai komunikator Program ZWC. Hal ini menjadikan warga ikut tergerak aktif berkontribusi karena Ketua RW mendukung dan ikut menyebarkan informasi. Ketua RW yang aktif dapat mendorong warga untuk terlibat dalam pemilahan sampah. Ketua RW pun memiliki kebijakan sendiri dalam mengatur petugas kebersihan dan mengingatkan warga bagi warga yang tidak mau melakukan pemilahan sampah karena sampahnya tidak akan diangkut petugas.
Selain itu, para Kader pun menjadi komunikator dalam Program ZWC, ialah warga yang secara sukarela membantu desa dalam melakukan Door To Door Education (DTDE), mengajak masyarakat menerapkan pola hidup zero waste melalui pemilahan sampah. Berdasarkan observasi yang peneliti lakukan, Kader berperan dalam komunikasi antar pribadi kepada masyarakat.

Kader bersama staf lapangan dan Ketua RW mengunjungi setiap rumah warga, memberikan edukasi mengenai Program ZWC, dan menginformasikan jadwal pengangkutan sampah yang telah terpilah. Sebelumnya, YPBB dan Ketua RW memberikan edukasi kepada para Kader dalam menginformasikan, menjelaskan isi poster, dan menjawab pertanyaan dari warga. Pada saat itu, peneliti melihat relasi yang baik antara warga dengan para Kader. Warga menjamu tim kampanye dengan suguhan makanan dan minuman dan menyambut kedatangan tim dengan ramah.

Berdasarkan hasil pengamatan yang dilakukan, terungkap bahwa pemilihan Ketua RW dan Kader sebagai komunikator dalam Program Zero Waste Cities merupakan langkah yang tepat dan berjalan efektif. Komunikator yang dipilih ialah orang yang memang sudah dikenal warga maka komunikasi pun berjalan lebih efektif dan pesan mudah disampaikan tanpa rasa curiga atau ragu. Selain itu, warga melihat bahwa Ketua RW dan Kader ikut aktif dalam program ini sehingga warga terdorong untuk ikut menyukseskan Program ZWC.

Program Zero Waste Cities memiliki pesan mengenai pemilahan sampah. Bagaimana kita memiliki pengetahuan dalam memilah sampah organik lunak, organik keras, non organik yang dapat 
diolah, dan non organik yang tidak dapat diolah. Saat dilakukan sosialisasi kepada kelurahan dan RW, tim kampanye menjelaskan mengenai adanya payung hukum yang mengatur yaitu UU No. 18 Tahun 2018 serta Peraturan Daerah Kota Bandung Nomor 9 Tahun 2018. Informasi tersebut banyak disampaikan saat awal sosialisasi untuk mengajak para stakeholder agar mendukung program. Pada umumnya, penyampaian pesan pada warga mengenai cara memilah sampah telah berhasil dilaksanakan.

Pengolahan pesan dalam Program ZWC pun sudah berjalan cukup efektif. Hal ini sesuai jumlah warga yang mampu memilah sampah sebanyak $80 \%$. Walaupun belum mencapai target, partisipasi Ketua RW, Kader, dan warga dalam program ini semakin baik.

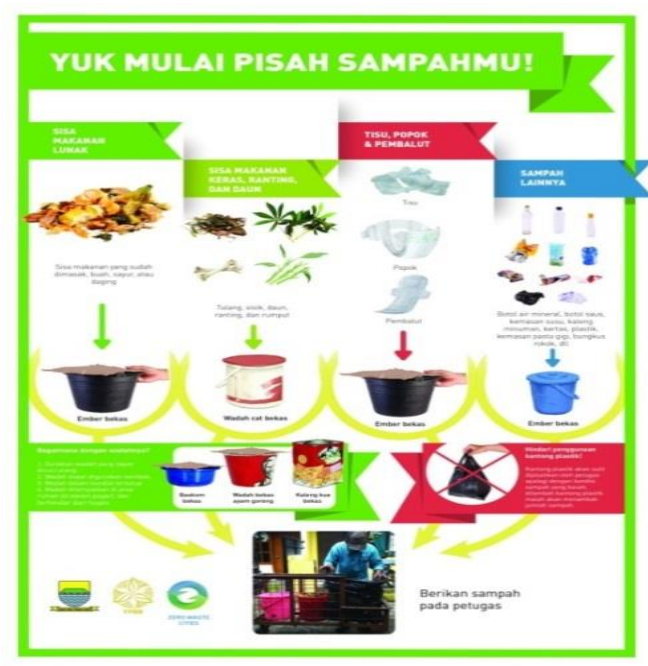

Gambar 6. Poster Door To Door Education Sumber : Program ZWC, 2019

YPBB sendiri menggunakan media poster dalam menyampaikan informasi mengenai zero waste dan pemilahan sampah, contohnya saat kegiatan Door To Door Education (DTDE). Kader akan menjelaskan mengenai cara pemilahan sampah dengan cara menunjukkan poster yang berisi tulisan jenis sampah beserta gambarnya. Setelah itu, Kader pun memberikan poster saat mendatangi rumah warga.

YPBB dalam menyampaikan pesan zero waste pun menggunakan media sosial WhatsApp karena komunikasi melalui grup ini membuat warga mudah berkomentar atau mengusulkan saran tanpa harus menunggu kegiatan pelatihan atau saat kumpul. Selain itu, komunikasi dalam grup ini memudahkan informasi cepat tersampaikan.

Program ZWC memiliki sasaran atau komunikan pada kelompok masyarakat pemukiman. Masyarakat pemukiman yang dimaksud ialah jenis pemukiman yang bukan dibuat oleh perusahaan pengembang (developer). Apabila pemukiman dari suatu perusahaan maka sampahnya akan dikelola perusahaan sendiri. Untuk itu, komunikan atau sasaran dalam program ini adalah wilayah RW yang memiliki karakteristik masyarakat rural dan telah melakukan pengumpulan sampah di lingkungannya. Petugas pengumpul berada di seluruh kawasan. Di mana koordinasi pembayaran petugas pengumpul dilakukan RW/RT, kawasan dengan TPS 3R, kawasan dengan kepadatan rendah, topografi datar, dan adanya dukungan ketua RW dan warga setempat. Adapun alasan pemilihan kawasan RW dengan karakteristik seperti di atas untuk memudahkan proses pengambilan dan pengelolaan sampah. Selain itu, dukungan Ketua RW dan para warga dalam mewujudkan Program ZWL dan ZWC bersifat partisipatif.

\section{SIMPULAN}

Berdasarkan hasil penelitian dapat disimpulkan bahwa Program ZWL meliputi beberapa tahapan kegiatan. Pertama, penentuan komunikator dari staf YPBB dan melibatkan pelatih (trainer), 
yakni orang yang diambil YPBB untuk memberikan pelatihan ZWL. Pelatih (trainer) tidak terikat sebagai staf tetap namun sebagai relawan (volunteer). Relawan dalam konteks ini yaitu orang yang secara sukarela melakukan tugas sebagai pelatih (trainer) YPBB, tetapi tidak tercatat sebagai staf YPBB. Sejak awal direkrut, pelatih (trainer) memang tidak diberikan gaji. Perekrutan pelatih (trainer), atau relawan mengalami beberapa tahapan, yakni melakukan pendaftaran lalu mengikuti kegiatan Training of Trainer (TOT). Tujuan dilakukan TOT adalah untuk memahami alur persampahan penyebab terbentuknya sampah mulai dari sumber daya alam, pengolahan menjadi produk, dijual dan didistribusikan, dibeli, dipakai di rumah hingga menjadi sampah dan berakhir di TPA, dan keikutsertaan magang selama kurang lebih 2-3 bulan. Kedua, tahapan program ZWL adalah proses pengolahan pesan yang disusun dalam satu dokumen untuk menjadi acuan bagi seluruh staf dan pelatih (trainer) dalam penyampaian informasi. Penyusunan pesan tersebut telah dilakukan sejak pertama kali didirikan divisi kampanye zero waste, yang ditambah aktualisasi di bagian yang diperlukan tanpa mengubah substansi. Ketiga dalam tahapan Program ZWL ialah penentuan media. Panitia menggunakan beberapa media pelatihan, seperti lembar (slide) persentasi, penggunaan media sampah organik dan non organik, keranjang takakura yakni keranjang yang berfungsi untuk mengompos sampah organik lembut yang dihasilkan dari rumah dan pembuatan lubang biopori. Keempat, penentuan komunikan oleh YPBB bersama mitra Dompet Dhuafa Volunteer (DDV) yang terdiri dari 28 orang dengan rentang usia 19-30 tahun. Secara umum tujuannya untuk belajar cara pengelolaan sampah secara baik dan benar. Adapun kegiatan diseminasi informasi pada Program ZWC dilakukan oleh Ketua RW, Kader, dan petugas kebersihan yang menjadi komunikator. Ketua RW melakukan komunikasi secara top down dan Kader melalui Door To Door Education (DTDE). Pesan yang disampaikan bersifat persuasif edukatif yang menekankan komunikan untuk melakukan pemilahan sampah. Media yang digunakan dalam penyampaikan pesan berupa poster sebagai media cetak, dan menggunakan media sosial berupa grup WhatsApp. Penggunaan media ini untuk menentukan komunikan pada program ZWC, yaitu kawasan di mana pihak RW dan warga memberikan dukungan yang positif terhadap program ini. Sesuai Program ZWL dan ZWC yang dilakukan YPBB, masyarakat yang telah dibina dan melakukan workshop belajar untuk konsisten dalam mengelola sampah dari lingkungan sendiri. Sampah organik dan non organik ternyata dapat dimanfaatkan dan didaur ulang kembali menjadi produk yang bermanfaat dan aman bagi alam. Maka, peneliti dalam rencana penelitian selanjutnya akan membuat sebuah rancangan model diseminasi informasi tentang program zero waste menggunakan pendekatan metode penelitian tindakan.

\section{DAFTAR PUSTAKA}

Arisyanti, P. (2018). Pengelolaan sampah untuk kesejahteraan masyarakat: Studi kasus di Kelurahan Bumi, Laweyan, Surakarta (Skripsi) [UIN Sunan Kalijaga, Yogyakarta]. http:/ / webcache.googleusercontent.c om/search?q=cache:D3SbuA7bgB4J:d igilib.uinsuka.ac.id/32912/1/14250074_BAB- 
I_IV-atau-V_DAFTAR-

PUSTAKA.pdf $+\& \mathrm{~cd}=1 \& \mathrm{hl}=\mathrm{id} \& \mathrm{ct}=\mathrm{cln}$ $\mathrm{k} \& \mathrm{gl}=\mathrm{id}$

Bahri, S. (2015). Strategi pengelolaan sampah oleh Dinas Kebersihan, Pertamanan dan Pemakaman di Kabupaten Tanggerang (Skripsi) [Universitas Sultan Ageng Tirtayasa, Serang]. http:/ / repository.fisipuntirta.ac.id/594/1/STRATEGI PENGELOLAAN SAMPAH OLEH DINAS KEBERSIHAN PERTAMANAN DAN PEMAKAMAN \%28DKPP\%29 DI KABUPATEN TA - Copy.pdf

Cangara, H. (2018). Perencanaan dan strategi komunikasi. Jakarta: Raja Grafindo Persada.

Creswell, J. (2016). Desain penelitian. Jakarta: KIK Press.

Diandara, C. M. (2017). Implementasi kebijakan pemerintah dalam pengelolaan daur ulang sampah di Kota Metro (Skripsi) [Universitas Lampung, Bandar Lampung]. http:/ / digilib.unila.ac.id/26116/

Djaffar, R. (2017). Diseminasi teknologi informasi pada masyarakat nelayan di Kabupaten Takalar dan Barru. Jurnal Penelitian Komunikasi Dan Opini Publik, 21(1), 73-87. https://jurnal.kominfo.go.id/index.p hp/jpkop/article/view/955/598

Komari, A. S., Abdulhak, I., \& Heryanto, N. (2013). Sikap ibu rumah tangga terhadap penerapan program zero waste lifestyle di Kelurahan Sukaluyu Kota Bandung. Jurnal Pendidikan Luar Sekolah, 9(2), 1-9. https://ejournal.upi.edu/index.php/ pls/article/view/5417/3713

Kusumajanti, Purnama, M., \& Priliantini, A. (2018). Diseminasi informasi publik oleh Humas Kementerian
Kelautan dan Perikanan Republik Indonesia dalam menumbuhkan public awareness: Studi kasus terkait penggunaan pukat hela dan pukat trawl pada nelayan di Kepulauan Seribu. Jurnal Komunikasi, Media Dan Informatika, 7(3), 116-126. https://jurnal.kominfo.go.id/index.p hp/komunika/article/view/1630/99 2

Mahyudin, R. P. (2017). Kajian permasalahan pengelolaan sampah dan dampak lingkungan di TPA (Tempat Pemrosesan Akhir) (Study waste problems and landfill environmental impact). Jukung: Jurnal Teknik Lingkungan, 3(1), 66-74. https://doi.org/10.20527/jukung.v3i 1.3201

Nurazizah. (2018). Peran pustakawan dalam diseminasi informasi via jurnal elektronik lokal dan dampaknya terhadap kepuasan pemustaka di UPT. Perpustakaan Unsyiah (Skripsi) [Universitas Islam Negeri Ar-Raniry, Darussalam]. https:/ / repository.arraniry.ac.id/id/eprint/4796/

Nurdiansyah, A. (2013). Efektivitas diseminasi informasi di Perpustakaan Kemitraan bagi pembaruan tata pemerintahan Jakarta menurut persepsi pengguna (Skripsi) [Universitas Islam Negeri Sunan Kalijaga, Yogyakarta]. http:/ / digilib.uinsuka.ac.id/12010/1/BAB I\%2C V\%2C DAFTAR PUSTAKA.pdf

Ordoñez, M., \& Serrat, O. (2017). Disseminating knowledge products. In Knowledge Solutions (pp. 871-878). Singapore: Springer. https:/ / doi.org/10.1007/978-981-100983-9_97

Prihandoyo, W. B. (2014). Efektivitas diseminasi informasi pertanian melalui 
media telepon genggam pada petani sayuran di Kecamatan Pacet Kabupaten Cianjur (Tesis) [Institut Pertanian Bogor (IPB), Bogor]. https:/ / repository.ipb.ac.id/handle/ $123456789 / 73028$

Purwaningrum, P. (2016). Upaya mengurangi timbunan sampah plastik di lingkungan. Indonesian Journal of Urban and Environmental Technology, $8(2)$, 141-147. https:/ / doi.org/10.25105/urbanenvir otech.v8i2.1421

Retnowati, E. (2014). Studi deskriptif diseminasi informasi pesan kebencanaan di kelompok masyarakat kawasan rawan bencana Desa Umbulharjo Kecamatan Cangkringan Kabupaten Selman Daerah Istimewa Yogyakarta (Skripsi) [Universitas Diponegoro, Semarang]. https:/ / ejournal3.undip.ac.id/index. php/interaksionline/article/view/7302/7062

Rodiah, S., Budiono, A., \& Rohman, A. S. (2018). Model diseminasi informasi komunikasi kesehatan masyarakat pedesaan di Kabupaten Bandung Barat. Jurnal Kajian Komunikasi, 6(2), 175-190.

https:/ / doi.org/10.24198/jkk.v6i2.17 771

Septiani, B. A., Arianie, D. M., Risman, V. F. A. A., Handayani, W., \&
Kawuryan, I. S. S. (2019). Pengelolaan sampah di Salatiga: Praktik dan tantangan. Jurnal Lingkungan, 17(1), 90-99.

https://doi.org/10.14710/jil.17.1.9099

Setyowati, R., \& Mulasari, S. A. (2013). Pengetahuan dan perilaku ibu rumah tangga dalam pengelolaan sampah plastik. Kesmas: National Public Health Jurnal, 7(12), 562-566. https://doi.org/10.21109/kesmas.v7i 12.331

Siswantini. (2017). Literasi pengelolaan sampah Kota Bandung (Disertasi). Universitas Padjadjaran, Sumedang.

Wahyudi, J., Prayitno, H. T., \& Astuti, A. D. (2018). Pemanfaatan limbah plastik sebagai bahan baku pembuatan bahan bakar alternatif. Jurnal Litbang, 14(1), 58-67. https://doi.org/10.33658/jl.v14i1.109

Widiarti, I. W. (2012). Pengelolaan sampah berbasis zero waste skala rumah tangga secara mandiri. Jurnal Sains Dan Teknologi Lingkungan, 4(2), 101113.

https://doi.org/10.20885/jstl.vol4.iss 2.art4

Yin, R. K. (2019). Studi kasus: Desain $\mathcal{E}$ metode. Jakarta: Raja Grafindo Persada. 
